\title{
Determination of digestible lysine and estimation of essential amino acid requirements for bullfrogs
}

\author{
Cleber Fernando M. Mansano ${ }^{\mathrm{a}, *}$, Beatrice Ingrid Macente ${ }^{\mathrm{b}}$, Thiago Matias T. Nascimento ${ }^{\mathrm{c}}$, Marcelo M. Pereira ${ }^{\mathrm{d}}$, \\ Edney P. da Silva ${ }^{\text {b }}$, Marta V. De Stéfani ${ }^{c}$ \\ a Programa de Pós-Graduação em Ciência e Tecnologia Animal, Univ. Estadual Paulista, Rodovia Comandante João Ribeiro de Barros, Km 651, Das Antas, $17900-000$ Dracena, SP, Brazil \\ b Faculdade de Ciências Agrárias e Veterinárias, Univ. Estadual Paulista, Via de Acesso Prof. Paulo Donato Castellane s/n, 14884-900 Jaboticabal, SP, Brazil \\ ' Centro de Aquicultura, UNESP - Univ. Estadual Paulista, Via de Acesso Prof. Paulo Donato Castellane s/n, 14884-900 Jaboticabal, SP, Brazil \\ ${ }^{d}$ Fundação Instituto de Pesca do Estado do Rio de Janeiro, Fonseca Ramos s/n, Terminal Rodoviário Roberto Silveira, sobreloja, 24030-020 Niterói, RJ, Brazil
}

\section{A R T I C L E I N F O}

\section{Article history:}

Received 25 November 2015

Received in revised form 2 March 2016

Accepted 3 March 2016

Available online 4 March 2016

\section{Keywords:}

Amino acid profile

Broken-line

Lysine

Nutritional requirement

\begin{abstract}
A B S T R A C T
The traditional method to determine the nutritional requirements of animals is based on individual doseresponse experiments that are time consuming and costly. One alternative to establish the dietary protein profile is the use of the ideal ratio between essential amino acids and digestible lysine to estimate essential amino acid requirements. The objective of this study was to determine the digestible lysine requirement of bullfrogs and to estimate essential amino acid requirements based on the ideal ratio. The experimental design was completely randomized and consisted of five treatments and three replicates. Six hundred froglets with an initial mean weight of $51.53 \pm 1.91 \mathrm{~g}$, identified through an implanted transponder, were used. The experimental diet (30.42\% digestible protein) was supplemented with five levels of lysine $\mathrm{HCl}(0,0.7,1.4,2.1$, and $2.8 \%)$, so that the diets contained 1.38, 2.11, 2.85, 3.65 and 4.39\% digestible lysine. The performance variables were feed intake, weight gain, feed conversion, specific growth rate, protein efficiency ratio, protein retention efficiency, and body protein and lysine deposition. The optimum level of digestible lysine was obtained at the intersection of the ascending line with the response plateau. Weight gain increased until reaching $222.7 \mathrm{~g}$ at $2.23 \%$ digestible lysine in the diet. The best feed conversion $(1.4 \mathrm{~g} / \mathrm{g})$ and body protein $(48.28 \mathrm{~g})$ and lysine $(4.07 \mathrm{~g})$ deposition were observed at 2.29\%, 2.33\% and 2.39\% digestible lysine, respectively. The digestible lysine requirement of bullfrogs is $2.71 \%$ of dry weight or $8.91 \%$ of dietary digestible protein, a level that provides the highest protein retention efficiency. The requirements of the other digestible amino acids estimated based on the concept of the ideal ratio of essential amino acids are (of dry weight): $2.16 \%$ arginine; $0.94 \%$ histidine; $1.34 \%$ isoleucine, $2.39 \%$ leucine; $0.79 \%$ methionine; $1.31 \%$ phenylalanine; $1.34 \%$ threonine; $0.23 \%$ tryptophan; $1.58 \%$ valine; $0.36 \%$ cystine, and $1.07 \%$ tyrosine.

Statement of Relevance: The estimate requirement of digestible essential amino acid using the concept of the ideal ratio permits the elaboration of diets with an appropriate amino acid, maximizing growth, protein utilization efficiency and carcass quality for bullfrogs.
\end{abstract}

(c) 2016 Elsevier B.V. All rights reserved.

\section{Introduction}

Brazilian frog farming has a great potential as a producer of highquality and low-fat animal protein. However, this is an area that needs to be better exploited through the use of tools that assist researchers, technicians and producers to maximize production and minimize costs within a productive (Dias et al., 2010) and sustainable process (Bosma and Verdegem, 2011), for a population that requires more food from fewer natural resources (Schneider et al., 2011). Within this context, it is first necessary to establish all nutritional requirements of

\footnotetext{
* Corresponding author.

E-mail address: clebermansano@yahoo.com.br (C.F.M. Mansano).
}

the species studied. Several concepts exist for this purpose (Glencross et al., 2007)

The method traditionally used for the determination of amino acid requirements in aquatic organisms relies on individual dose-response experiments of each amino acid, which are time consuming and costly (Small and Soares, 1998). The concept of the ideal amino acid ratio is based on the balance of free or protein-bound amino acids readily available for digestion and metabolism to obtain the optimum productive performance (Sakomura and Rostagno, 2007). Theoretically, the ideal amino acid ratio should be identical to the amino acid profile of the body and the animal's needs for growth and maintenance of metabolic activities (Li et al., 2009). Thus, the amino acid profile of body protein is the concept most commonly used in studies to represent the amino acid requirements of growing animals (Kaushik, 1998; Kim and Lall, 
2000; Abimorad et al., 2010; Grisdale-Helland et al., 2011; Cao et al., 2012).

The advantage of this concept is that it can be easily adapted and modified to different situations, especially the formulation of nutritionally complete diets. The ideal ratios remain relatively stable, irrespective of the substitution of ingredients in the nutritional composition. Normally, the most limiting essential amino acid (EAA) is used to estimate the requirement of the other amino acids by means of the ideal EAA ratio of the body (Twibell et al., 2003; Wang et al., 2005).

Lysine has been used as the reference amino acid in almost all studies because it is the main amino acid for protein deposition in the animal and is necessary for metabolic interactions with other amino acids (Ball et al., 2007). In view of the important role of lysine as a reference for the absorption of other amino acids, its requirement should be defined as accurately as possible based on the concept of the ideal ratio of EAA in order to avoid biased estimates of the requirements of other amino acids.

In view of the above considerations, the objective of this study was to establish the digestible lysine requirement of bullfrogs (based on dose-response experiments) by evaluating productive performance and efficiency of nutrient utilization. Additionally, the nutritional requirements of other amino acids were estimated by determining the ideal ratio between EAA and the level of digestible lysine that provided the best performance results. The results of this study will provide the scientific basis for the formulation of adequate diets, increasing their assimilation and consequently reducing environmental impacts.

\section{Material and methods}

The experiment was conducted between December 2013 and March 2014 at the Frog Farming Sector and Laboratory of Nutrition of Aquatic Organisms, Aquaculture Center of Universidade Estadual Paulista (UNESP), Jaboticabal Campus.

All procedures were approved by the Ethics Committee on Animal Use of the School of Agricultural and Veterinary Sciences, UNESP (Protocol No. 011866/12), and were conducted according to the ethical principles adopted by the Brazilian College of Animal Experimentation (Colégio Brasileiro de Experimentação Animal - COBEA).

\subsection{Biological material and facilities}

Six hundred froglets with an initial weight of $51.53 \pm 1.91 \mathrm{~g}$ were randomly allocated to 15 experimental pens $\left(3 \mathrm{~m}^{2}\right)$ in the fattening facility. The pens were equipped with linearly arranged vibrating feeders, shelters, and water troughs. All animals were identified by implantation of a bioglass-encapsulated transponder (Animal Tag, ISO FDX-B, $134.2 \mathrm{kHz}$ ) compatible with norms ISO 11784, 11,785 and NBR 14766, measuring $2.2 \times 12.2 \mathrm{~mm}$, according to the method of Mansano et al. (2013).

Water was supplied continuously from an artesian well at a temperature of about $28^{\circ} \mathrm{C}$. The pens were cleaned daily and the water troughs were emptied, unconsumed feed was removed, and the water was exchanged. The temperature and humidity in the fattening facility

Table 1

Formula and nutritional composition of the diet used for bullfrogs.

\begin{tabular}{|c|c|c|c|c|c|}
\hline & \multicolumn{5}{|c|}{ Level of digestible lysine (\%) } \\
\hline & 1.38 & 2.11 & 2.85 & 3.65 & 4.39 \\
\hline \multicolumn{6}{|l|}{ Ingredient (\%) } \\
\hline Corn grain & 23.00 & 23.00 & 23.00 & 23.00 & 23.00 \\
\hline Corn gluten mean & 20.00 & 20.00 & 20.00 & 20.00 & 20.00 \\
\hline Wheat bran & 19.56 & 19.56 & 19.56 & 19.56 & 19.56 \\
\hline Hydrolyzed feather meal & 15.03 & 15.03 & 15.03 & 15.03 & 15.03 \\
\hline Salmon by-product meal & 10.00 & 10.00 & 10.00 & 10.00 & 10.00 \\
\hline Soybean meal & 6.00 & 6.00 & 6.00 & 6.00 & 6.00 \\
\hline L-Lysine $\mathrm{HCl}-78 \%$ & 0.00 & 0.70 & 1.40 & 2.10 & 2.80 \\
\hline Glutamic acid - 99\% & 3.50 & 2.80 & 2.10 & 1.40 & 0.70 \\
\hline DL-methionine - 99\% & 0.46 & 0.46 & 0.46 & 0.46 & 0.46 \\
\hline L-Histidine - 99\% & 0.13 & 0.13 & 0.13 & 0.13 & 0.13 \\
\hline L-Tryptophan - 98\% & 0.03 & 0.03 & 0.03 & 0.03 & 0.03 \\
\hline Monopotassium phosphate & 1.77 & 1.77 & 1.77 & 1.77 & 1.77 \\
\hline Mineral and vitamin supplement ${ }^{\mathrm{a}}$ & 0.50 & 0.50 & 0.50 & 0.50 & 0.50 \\
\hline $\mathrm{BHT}^{\mathrm{b}}$ & 0.02 & 0.02 & 0.02 & 0.02 & 0.02 \\
\hline \multicolumn{6}{|c|}{ Composition analyzed (dry matter basis) } \\
\hline Crude protein $(\%)^{\mathrm{c}}$ & 44.22 & 43.80 & 43.23 & 44.12 & 43.86 \\
\hline Digestible protein (\%) & 30.69 & 30.39 & 29.95 & 30.62 & 30.44 \\
\hline Crude ether extract $(\%)^{\mathrm{d}}$ & 6.71 & 6.68 & 6.68 & 6.70 & 6.80 \\
\hline \multicolumn{6}{|c|}{ Crude and digestible essential amino acids (\%) ${ }^{\mathrm{e}}$ (dry matter basis) } \\
\hline Arginine & ${ }^{f} 2.73(2.34)$ & $2.66(2.29)$ & $2.66(2.29)$ & $2.69(2.32)$ & $2.63(2.27)$ \\
\hline Histidine & $0.95(0.80)$ & $0.96(0.80)$ & $0.96(0.80)$ & $0.96(0.80)$ & $0.94(0.79)$ \\
\hline Isoleucine & $2.07(1.69)$ & $2.04(1.67)$ & $2.04(1.66)$ & $1.99(1.63)$ & $2.00(1.64)$ \\
\hline Leucine & $5.32(4.39)$ & $5.26(4.35)$ & $5.17(4.27)$ & $5.15(4.25)$ & $5.15(4.25)$ \\
\hline Lysine & $1.70(1.38)$ & $2.45(2.11)$ & $3.19(2.85)$ & $3.99(3.65)$ & $4.74(4.39)$ \\
\hline Methionine & $1.49(1.32)$ & $1.48(1.31)$ & $1.48(1.31)$ & $1.47(1.30)$ & $1.49(1.32)$ \\
\hline Phenylalanine & $2.41(1.65)$ & $2.37(1.62)$ & $2.38(1.62)$ & 2.39 (1.69) & 2.39 (1.68) \\
\hline Threonine & $1.90(1.35)$ & $1.92(1.36)$ & $1.86(1.32)$ & $1.89(1.34)$ & $1.89(1.34)$ \\
\hline Tryptophan & $0.33(0.26)$ & $0.32(0.25)$ & $0.31(0.24)$ & $0.30(0.24)$ & $0.32(0.25)$ \\
\hline Valine & $2.98(2.49)$ & $2.95(2.46)$ & $2.92(2.42)$ & $2.96(2.47)$ & $2.95(2.46)$ \\
\hline
\end{tabular}

${ }^{a}$ Moisture (\%) 2.0; ashes (\%) 71.6442; choline (mg/kg) 30,000; magnesium (\%) 0.0085; sulfur (\%) 1.1589; iron (mg/kg) 25,714; copper (mg/kg) 1960; manganese (mg/kg) 13,345; zinc

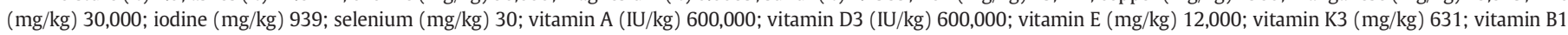

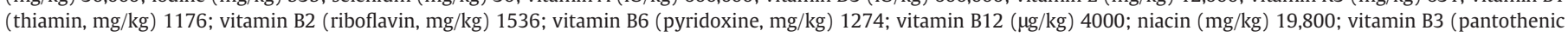
acid, mg/kg) 3920; folic acid (mg/kg) 192; biotin (mg/kg) 20; ascorbic acid (mg/kg) 40,250.

b Butylated hydroxytoluene.

c Method of Dumas in a Leco 528 LC apparatus (Etheridge et al., 1998).

d Acid hydrolysis (AOAC, 1995).

e Acid hydrolysis and ion-exchange chromatography (HPLC).

${ }^{f}$ Crude AA (Digestible AA). 
were measured daily with a digital thermo-hygrometer. The mean maximum and minimum temperature and relative humidity were, respectively, $31.6 \pm 1.61{ }^{\circ} \mathrm{C}$ and $21.9 \pm 1.14{ }^{\circ} \mathrm{C}$ and $80.4 \pm 4.53 \%$ and $32.5 \pm 10.12 \%$. According to Braga and Lima (2001) and Figueiredo et al. (2001), the best productive performance of bullfrogs is obtained at a temperature of 25 to $30^{\circ} \mathrm{C}$, a value close to the mean temperatures observed in the present study.

\subsection{Experimental diets}

Protein, ether extract and digestible amino acid data were used for formulation of the diets (Mansano, 2015). For diet preparation, the ingredients were mixed and grounded using a hammer mill (Model 4, D'Andrea, Limeira, Brazil) fitted with a $0.8 \mathrm{~mm}$ screen sieve. Diets were extruded at a diameter of 4 to $6 \mathrm{~mm}$, under identical processing conditions using a single-screw extruder (Mab 400S, Extrucenter, Monte Alto, Brazil) with an average extrusion capacity of $150 \mathrm{~kg} \mathrm{~h}^{-1}$. The extruder pre-conditioning temperature was maintained above $90{ }^{\circ} \mathrm{C}$. The water and steam additions, screw speed and food flux were adjusted according to the dietary formulations, and the extrusion temperature varied between 125 and $135{ }^{\circ} \mathrm{C}$, and dried in a dryer at $105^{\circ} \mathrm{C}$ temperature for $1 \mathrm{~h}$.

For evaluation of the digestible lysine requirement of bullfrogs, an experimental diet containing 30.42\% digestible protein (with the minimum lysine possible) was formulated and supplemented with five levels of lysine $\mathrm{HCl}(0,0.7,1.4,2.1$, and $2.8 \%)$ (Table 1$)$. The ratio of the other amino acids was maintained according to the previously determined body amino acid profile of bullfrogs (3.69\% arginine; $1.61 \%$ histidine; $2.29 \%$ isoleucine; $4.08 \%$ leucine; $4.63 \%$ lysine; $1.35 \%$ methionine; $2.24 \%$ phenylalanine; $2.28 \%$ threonine; $0.39 \%$ tryptophan; $2.70 \%$ valine).

\subsection{Management and laboratory tests}

The diets were offered ad libitum all the time in vibrating feeders. Leftovers were removed, stored in a freezer, and subsequently dried in a forced air circulation oven for calculation of the amount of ingested feed.

The animals were weighed on a precision scale $(0.01 \mathrm{~g})$ at the beginning and at the end of the experimental period (90 days) for determination of the performance variables (weight gain, feed intake, apparent feed conversion, specific growth rate, and protein efficiency ratio), crude protein and lysine deposition, and protein retention efficiency.

First, a sample of 20 animals representing the whole lot was obtained. At the end of the experiment, three animals per pen were sampled, transferred to polyethylene boxes with a small water layer, and fasted for $48 \mathrm{~h}$. After this period, the animals were stunned by immersion in ice and the spine was sectioned. The animals were frozen for subsequent grinding in a meat grinder, lyophilized, ground again in a ball mill, and sent for determination of dry matter and crude protein.

For analysis of body nutrients, crude protein was determined by the method of Dumas in a Leco 528 LC apparatus (Etheridge et al., 1998). Dry matter was obtained in an oven at $105{ }^{\circ} \mathrm{C}$ for $12 \mathrm{~h}$. The methods described by the AOAC (1995) were used for the analyses. Total amino acids were determined by acid hydrolysis and ion-exchange chromatography (HPLC) in the Laboratory of Protein Sources, Universidade Estadual de Campinas (UNICAMP) according to the method of White et al. (1986) and Hagen et al. (1989).

At the end of the study and after analysis of the data for determination of the most appropriate level of digestible lysine, the ratio of digestible protein to adequate digestible lysine was established for fattening bullfrogs. Additionally, the amino acid profile, called the "ideal EAA ratio", was determined based on the ratio of body amino acids of bullfrogs according to the method of Arai (1981).

\subsection{Experimental design and statistical analysis}

A completely randomized design consisting of five treatments and three replicates was used. For the evaluation of weight gain, each animal was considered one replicate. For evaluation of the other performance parameters and nutrient deposition, each pen was considered one replicate, for a total of three replicates per treatment. The values of the performance variables and body protein and lysine deposition were obtained at the intersection of the ascending line with the response plateau, determining the minimum digestible lysine level for each variable. These variables were obtained by the broken-line model using the SAS software (SAS Institute, 2008).

\section{Results}

With respect to productive performance, nutrient deposition and nutrient retention efficiency, the addition of lysine directly influenced $(P<0.05)$ the responses of the animals (Table 2$)$.

The mean weight gain, specific growth rate, feed intake, apparent feed conversion, protein efficiency ratio, protein deposition, lysine deposition and protein retention efficiency were fitted with a brokenline model, in which the breakpoint of the line was considered the ideal level of digestible lysine (Table 3 ). The best weight gain $(222.7 \mathrm{~g})$ and feed conversion $(1.40 \mathrm{~g} / \mathrm{g})$ of the animals estimated with the broken-line model were obtained at $2.23 \%$ and $2.29 \%$ digestible lysine, respectively. The highest specific growth rate (1.85\%/day) was obtained at $2.21 \%$ digestible lysine in the diet (Table 3 ). The optimum

Table 2

Mean values of the productive performance variables, nutrient deposition and nutrient retention efficiency of bullfrogs fed diets containing different levels of digestible lysine.

\begin{tabular}{|c|c|c|c|c|c|c|c|}
\hline & \multicolumn{5}{|c|}{ Dietary level of digestible lysine (\%) } & \multirow{2}{*}{$\begin{array}{l}\text { ANOVA } \\
P \text {-value }\end{array}$} & \multirow[t]{2}{*}{$\mathrm{F}$} \\
\hline & 1.38 & 2.11 & 2.85 & 3.65 & 4.39 & & \\
\hline Live weight gain (g) & $142.34 \pm 7.30$ & $210.93 \pm 12.08$ & $217.77 \pm 5.81$ & $231.71 \pm 5.24$ & $218.50 \pm 12.74$ & 0.0001 & 29.68 \\
\hline Specific growth rate (\%/day) & $1.48 \pm 0.02$ & $1.81 \pm 0.04$ & $1.85 \pm 0.06$ & $1.91 \pm 0.04$ & $1.81 \pm 0.07$ & 0.0001 & 22.52 \\
\hline Feed intake $(\mathrm{g})$ & $235.26 \pm 4.08$ & $306.64 \pm 13.03$ & $306.99 \pm 12.51$ & $325.93 \pm 12.76$ & $304.60 \pm 11.61$ & 0.0001 & 19.09 \\
\hline Apparent feed conversion $(\mathrm{g} / \mathrm{g})$ & $1.66 \pm 0.08$ & $1.45 \pm 0.02$ & $1.41 \pm 0.06$ & $1.41 \pm 0.02$ & $1.40 \pm 0.04$ & 0.0013 & 10.42 \\
\hline Protein efficiency ratio $(\mathrm{g} / \mathrm{g})$ & $1.97 \pm 0.10$ & $2.27 \pm 0.04$ & $2.36 \pm 0.11$ & $2.28 \pm 0.04$ & $2.28 \pm 0.04$ & 0.0001 & 22.52 \\
\hline Protein deposition $(\mathrm{g})$ & $26.69 \pm 1.25$ & $43.18 \pm 2.39$ & $45.28 \pm 0.68$ & $52.26 \pm 1.18$ & $47.30 \pm 2.87$ & 0.0001 & 54.08 \\
\hline Lysine deposition (g) & $2.16 \pm 0.10$ & $3.53 \pm 0.20$ & $3.86 \pm 0.05$ & $4.26 \pm 0.11$ & $4.09 \pm 0.26$ & 0.0001 & 53.85 \\
\hline Protein retention efficiency (\%) & $61.55 \pm 3.13$ & $70.04 \pm 1.18$ & $79.29 \pm 3.89$ & $70.15 \pm 0.53$ & $81.49 \pm 1.19$ & 0.0001 & 23.05 \\
\hline
\end{tabular}

Values are means of three replicates \pm standard deviation.

Live weight gain $(\mathrm{g})=$ (final weight - initial weight).

Specific growth rate $(\% /$ day $)=(((\ln ($ final weight $)-\ln ($ initial weight $)) /($ time $($ days $)))$.

Apparent feed conversion $(\mathrm{g} / \mathrm{g})=(($ feed intake $) /($ live weight gain $))$.

Protein efficiency ratio $(\mathrm{g} / \mathrm{g})=(($ live weight gain $) /($ crude protein ingested $))$.

Nutrient deposition $(\mathrm{g})=(($ live weight gain $\times$ nutrient content in the body $) / 100))$.

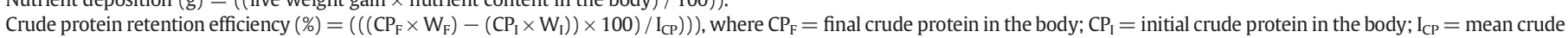
protein intake of the portion; $\mathrm{W}_{\mathrm{I}}, \mathrm{W}_{\mathrm{F}}=$ mean initial and final live weight of the portion. 
Table 3

Equations fitted with the broken-line model for the productive performance variables, nutrient deposition and nutrient retention efficiency of bullfrogs fed diets containing different levels of digestible lysine.

\begin{tabular}{lll}
\hline Variable & $\begin{array}{l}\text { Optimum level of } \\
\text { digestible lysine }(\%)\end{array}$ & $\mathrm{R}^{2}$ \\
\hline $\begin{array}{l}\text { Live weight gain }(\mathrm{g}) \\
\mathrm{y}=222.7-91.4489(2.2283-\mathrm{x})\end{array}$ & 2.23 & 0.8997 \\
$\begin{array}{l}\text { Specific growth rate }(\% / \text { day }) \\
\mathrm{y}=1.8556-0.4356(2.2122-\mathrm{x})\end{array}$ & 2.21 & 0.8617 \\
$\begin{array}{l}\text { Feed intake }(\mathrm{g}) \\
\quad \mathrm{y}=312.50-95.1733(2.1616-\mathrm{x})\end{array}$ & 2.16 & 0.8365 \\
$\begin{array}{l}\text { Apparent feed conversion }(\mathrm{g} / \mathrm{g}) \\
\quad \mathrm{y}=1.4044-0.2667(2.2958-\mathrm{x})\end{array}$ & 2.29 & 0.8047 \\
$\begin{array}{l}\text { Protein efficiency ratio }(\mathrm{g} / \mathrm{g}) \\
\mathrm{y}=2.3078-0.4000(2.1944-\mathrm{x})\end{array}$ & 2.19 & 0.7528 \\
$\begin{array}{l}\text { Protein deposition }(\mathrm{g}) \\
\mathrm{y}=48.2789-22.0000(2.3316-\mathrm{x})\end{array}$ & 2.33 & 0.8901 \\
$\begin{array}{c}\text { Lysine deposition }(\mathrm{g}) \\
\mathrm{y}=4.0689-2.3968(2.3968-\mathrm{x})\end{array}$ & 2.39 & 0.9288 \\
$\begin{array}{c}\text { Protein retention efficiency }(\%) \\
\mathrm{y}=76.9756-11.3111(2.7135-\mathrm{x})\end{array}$ & 2.71 & 0.7499 \\
\hline
\end{tabular}

level of digestible lysine in the diet was similar for maximum protein (48.28 g) and lysine deposition (4.07 g) in the animal's body and maximum protein retention (77.0\%) (2.33, 2.39 and $2.71 \%$, respectively). The best protein efficiency ratio $(2.3 \mathrm{~g} / \mathrm{g})$ was observed at $2.19 \%$ digestible lysine in the diet (Table 3).

The optimum level of digestible lysine $(2.71 \%)$ obtained with the equation for protein retention efficiency was used to calculate the ideal amino acid profile for bullfrogs. Table 4 shows the percentage of EAA in the body of bullfrogs, the EAA/乏EAA ratio (Arai, 1981), and the ideal EAA profile for the species. To determine the EAA profile, the requirement of the other digestible essential amino acids was estimated based on the appropriate level of digestible lysine determined in this dose-response study.

The estimated EAA requirements for the diet of bullfrogs were: 2.16\% arginine; $0.94 \%$ histidine; $1.34 \%$ isoleucine, $2.39 \%$ leucine; $2.71 \%$ lysine (determined in this study); $0.79 \%$ methionine; $1.31 \%$ phenylalanine; $1.34 \%$ threonine; $0.23 \%$ tryptophan, $1.58 \%$ valine, $0.36 \%$ cystine and $1.07 \%$ tyrosine (Table 4 ).

\section{Discussion}

Purified or semi-purified diets are used in most dose-response studies for determination of the amino acid requirements of aquatic organisms. These diets may negatively influence the growth of the

\section{Table 4}

Digestible essential amino acid (EAA) requirements of growing bullfrogs calculated based on the concept of the ideal ratio of digestible EAA to digestible dietary protein.

\begin{tabular}{|c|c|c|c|}
\hline & $\begin{array}{l}\% \text { amino acids of body } \\
\text { protein in growing } \\
\text { bullfrogs }{ }^{1}\end{array}$ & $\begin{array}{l}\mathrm{EAA} / \Sigma \mathrm{EAA} * 1000 \\
(\text { Arai, } 1981)\end{array}$ & $\begin{array}{l}\text { Ideal EAA } \\
\text { profile }(\%)^{2}\end{array}$ \\
\hline Arginine & 6.73 & 133.04 & 2.16 \\
\hline Histidine & 2.94 & 58.21 & 0.94 \\
\hline Isoleucine & 4.18 & 82.62 & 1.34 \\
\hline Leucine & 7.45 & 147.33 & 2.39 \\
\hline Lysine & 8.46 & 167.18 & 2.71 \\
\hline Methionine & 2.47 & 48.78 & 0.79 \\
\hline Phenylalanine & 4.09 & 80.82 & 1.31 \\
\hline Threonine & 4.17 & 82.41 & 1.34 \\
\hline Tryptophan & 0.70 & 13.92 & 0.23 \\
\hline Valine & 4.93 & 97.39 & 1.58 \\
\hline Cystine & 1.13 & 22.37 & 0.36 \\
\hline Tyrosine & 3.33 & 65.93 & 1.07 \\
\hline $\mathrm{\Sigma EAA}+\mathrm{Cys}+\mathrm{Tyr}$ & 50.58 & & \\
\hline
\end{tabular}

\footnotetext{
1 Determined in a previous study.

2 Estimated requirement of the other digestible EAA in relation to digestible lysine requirement: $(2.71$ / 167.18) $\times$ result of the formula of Arai (1981).
}

animals because of a reduction in feed intake (Berge et al., 2002), especially when the diets are deficient in EAA, particularly lysine (Yamamoto et al., 2001; Dabrowski et al., 2007). In the present study, the bullfrogs were fed practical diets supplemented with synthetic amino acids and exhibited satisfactory mean values of growth and feed conversion for the environmental conditions, even when the diets were deficient in lysine. The growth results indicated that lysine is essential for bullfrogs, which were able to utilize L-lysine in practical diets.

Feed intake increased with increasing inclusion level of lysine in the diet until reaching its peak, estimated at $2.16 \%$ digestible lysine. The same pattern has been reported by Encarnação et al. (2004) for rainbow trout, by Furuya et al. (2006) and Bonfim et al. (2010) for Nile tilapia, and by Grisdale-Helland et al. (2011) for Atlantic cod. According to Furuya et al. (2004), feed intake is directly related to the increase in lysine levels.

According to Bureau and Encarnação (2006), an imbalance in dietary amino acids can cause a reduction in feed intake and in the efficiency of EAA utilization. This proposal was confirmed by Yamamoto et al. (2000) who tested the self-selection of diets by rainbow trout and observed that these animals prefer diets with an adequate amino acid balance.

The optimum level of digestible lysine (2.23\%) estimated for the best weight gain of bullfrogs ( $222.7 \mathrm{~g}$ ) was similar to the value reported by Encarnação et al. (2004) for rainbow trout (2.28\%) using diets with $40 \%$ digestible protein.

Feed conversion improved with the inclusion of up to $2.29 \%$ digestible lysine in the diets, a value similar that observed for feed intake and live weight gain. These results indicate that the ideal level of digestible lysine in practical diets for bullfrogs can drastically change feed conversion, with a diet that is more concentrated in a certain nutrient, such as lysine, improving feed conversion (Sakomura and Rostagno, 2007). The best feed conversion estimated $(1.40 \mathrm{~g} / \mathrm{g})$ was better than that reported by Castro et al. (2014a,b) of 2.11 and $2.13 \mathrm{~g} / \mathrm{g}$, respectively. These authors used commercial carnivorous fish feeds for bullfrogs, demonstrating the importance of an appropriately balanced amino acid ratio in the diet for these animals.

The highest specific growth rate (1.85\% per day) estimated at $2.21 \%$ digestible lysine was higher than that observed by Martínez et al. (2004) for Rana perezi (1.08\% per day) fed a diet containing $46 \%$ crude protein.

The deposition of protein and lysine showed the same trend, reaching maximum values at $2.33 \%$ and $2.39 \%$ digestible lysine, respectively. Furuya et al. (2006) also found greater protein deposition in the body composition of Nile tilapia with a linear increase in digestible lysine levels in the diet. The same fact was reported by Encarnação et al. (2004, 2006) and by El-Haroun and Bureau (2006) for lysine deposition in rainbow trout.

The best digestible lysine level (2.19\%) estimated for the highest protein efficiency ratio $(2.3 \mathrm{~g} / \mathrm{g}$ ) of bullfrogs was similar to the $2.17 \%$ crude lysine reported by Tibaldi and Lanari (1991) for sea bass (Dicentrarchus zabrax L.) and the $2.16 \%$ crude lysine estimated by Forster and Ogata (1998) for juvenile red sea bream (Pagrus major). However, in contrast to the present study, these authors used crude lysine. Olvera-Novoa et al. (2007) found a protein efficiency ratio of $1.93 \mathrm{~g} / \mathrm{g}$ for bullfrogs fed $42 \%$ crude protein, a value lower than that observed in the present study $(2.3 \mathrm{~g} / \mathrm{g})$.

The choice of protein retention efficiency to determine the digestible lysine requirements of bullfrogs (2.71\%) is biologically more adequate compared to the other variables analyzed in this study, because amino acids are retained in protein and variables considering weight gain may be influenced by the gain provided by fat (Gaylord and Barrows, 2009).

The concept of the ideal amino acid ratio has been used to estimate the requirements of all EAA when one is known, based on the ideal ratio between one amino acid and all EAA in animal tissues (Arai, 1981; Kaushik, 1998; Kim and Lall, 2000). The estimate requirement 
of digestible EAA using the concept of the ideal ratio permits the elaboration of diets with an appropriate amino acid balance (Fuller et al., 1989; Wang and Fuller, 1989; Boisen et al., 2000; Dari et al., 2005; Abimorad et al., 2010), maximizing growth, protein utilization efficiency and carcass quality of bullfrogs. The digestible lysine requirement of bullfrogs ( $2.71 \%$ of dry weight diet) was not so different from the requirements of carnivorous fish species (Arai, 1981; Kaushik, 1998; Kim and Lall, 2000).

\section{Conclusion}

The digestible lysine requirement of bullfrogs is $2.71 \%$ of dry weight or $8.91 \%$ of dietary digestible protein, a level that provides the highest protein retention efficiency. The requirements of the other digestible amino acids estimated based on the concept of the ideal ratio of EAA are (of dry weight): $2.16 \%$ arginine; $0.94 \%$ histidine; $1.34 \%$ isoleucine, $2.39 \%$ leucine; $0.79 \%$ methionine; $1.31 \%$ phenylalanine; $1.34 \%$ threonine; $0.23 \%$ tryptophan; $1.58 \%$ valine; $0.36 \%$ cystine, and $1.07 \%$ tyrosine.

\section{Acknowledgments}

We thank the state funding agency Fundação de Amparo à Pesquisa do Estado de São Paulo (FAPESP) for the financial support (2012/039140 and 2012/13618-0). We also thank the technician Marcio Roberto Reche for help with the study.

\section{References}

Abimorad, E.G., Favero, G.C., Squassoni, G.H., Carneiro, D., 2010. Dietary digestible lysine requirement and essential amino acid to lysine ratio for pacu Piaractus mesopotamicus. Aquac. Nutr. 16, 370-377.

AOAC (Association of Official Analytical Chemists), 1995. Official Methods of Analysis. 16th ed. Association of Analytical Chemists, Arlington, Virginia, USA.

Arai, S., 1981. A purified test diet for coho salmon, Oncorhynchus kisutch, fry. Bull. Jpn. Soc Sci. Fish. 47, 547-550

Ball, R.O., Urschel, K.L., Pencharz, P.B., 2007. Nutritional consequences of interspecies differences in arginine and lysine metabolism. J. Nutr. 137, 1626-1641.

Berge, G.E., Sveier, H., Lied, E., 2002. Effects of feeding Atlantic salmon (Salmo salar L.) imbalanced levels of lysine and arginine. Aquac. Nutr. 8, 239-248.

Boisen, S., Hvelplund, T., Weisbjerg, M.R., 2000. Ideal amino acid profiles as a basis for feed protein evaluation. Livest. Prod. Sci. 64, 239-251.

Bomfim, M.A.D., Lanna, E.T.A., Donzele, J.L., Quadros, M., Ribeiro, F.B., Sousa, M.P., 2010 Níveis de Lisina digestível, com base no conceito de proteína ideal, em rações para alevinos de tilápia-do-Nilo. R. Bras. Zootec. 39, 1-8.

Bosma, R.H., Verdegem, M.C.J., 2011. Sustainable aquaculture in ponds: principles, practices and limits. Livest. Sci. 139, 58-68.

Braga, L.G.T., Lima, S.L., 2001. Influence of environmental temperature on the bullfrog performance, Rana catesbeiana (Shaw, 1802) in the growing phase. R. Bras. Zootec. 30, 1659-1663.

Bureau, D.P., Encarnação, P.M., 2006. Adequately defining amino acid requirement of fish the case example of lysine. In: Cruz-Suárez, E., Ricque-Marie, R., Tapia-Salazar, M., Nieto-López, M.G., Villarreal-Cavazos, D.A., Peullo-Cruz, A.C., García-Ortega, A. (Eds.), Avances en Nutrición Acuícola VIII: VIII Simposium Internacional de Nutrición Acuícola. Universidad Autónoma de Nuevo Leon, Nuevo Leon, Mexico, pp. 29-53.

Cao, J.M., Chen, Y., Zhu, X., Huang, Y.H., Zhao, H.X., Li, G.L., Lan, H.B., Chen, B., Pan, B., 2012. A study on dietary L-lysine requirement of juvenile yellow catfish Pelteobagrus fulvidraco. Aquac. Nutr. 18, 35-45.

Castro, C.S., Argentim, D., Novelli, D.P., Costa, J.M., Menezes, C.S.M., Neto, A.C., Vieira, J.C.S., Padilha, P.M., Agostinho, C.A., 2014a. Feed digestibility and productive performance of bullfrogs raised in cages and fed in different periods and high frequency. Aquaculture 433, 1-5.

Castro, C.S., Ribeiro, R.R., Agostinho, L.M., Santos, A.A.D., Carmelin, C.A., Chan, R.V., Neto J.F., Agostinho, C.A., 2014b. Polyculture of frogs and tilapia in cages with high feeding frequency. Aquac. Eng. 61, 43-48.

Dabrowski, K., Arslan, M., Terjesen, B.F., Zhang, Y., 2007. The effect of dietary indispensable amino acid imbalances on feed intake: is there a sensing of deficiency and neural signaling present in fish? Aquaculture 268, 136-142.

Dari, R.L., Penz, J., Kessler, A.M., Jost, H.C., 2005. Use of digestible amino acids and the concept of ideal protein in feed formulation for broilers. J. Appl. Poult. Res. 14, 195-203.

Dias, D.C., Stéfani, M.V., Ferreira, C.M., França, F.M., Ranzani-Paiva, M.J.T., Santos, A.A. 2010. Haematologic and immunologic parameters of bullfrogs, Lithobates catesbeianus, fed probiotics. Aquac. Res. 41, 1064-1071.

El-Haroun, E.R., Bureau, D.P., 2006. Comparison of the bioavailability of lysine in blood meals of various origins to that of L-lysine $\mathrm{HCl}$ for rainbow trout (Oncorhynchus mykiss). Aquaculture 262, 402-409.

Encarnação, P., Lange, C., Rodehutscord, M., Hoehlerc, D., Bureau, W., Bureau, D.P., 2004 Diet digestible energy content affects lysine utilization, but not dietary lysine requirements of rainbow trout (Oncorhynchus mykiss) for maximum growth. Aquaculture 235, 569-586.

Encarnação, P., Lange, C., Bureau, D.P., 2006. Diet energy source affects lysine utilization for protein deposition in rainbow trout (Oncorhynchus mykiss). Aquaculture 261, $1371-1381$

Etheridge, R.D., Pesti, G.M., Foster, E.H., 1998. A comparison of nitrogen values obtained utilizing the Kjeldahl nitrogen and Dumas combustion methodologies (Leco CNS 2000 ) on samples typical of an animal nutrition analytical laboratory. Anim. Feed Sci. Technol. 73, 21-28.

Figueiredo, M.R.C., Lima, S.L., Agostinho, C.A., Baêta, F.C., Weigert, S.C., 2001. Acclimatized incubators for environmental experiments with frogs, in cages. R. Bras. Zootec. 30, $1135-1142$.

Forster, I., Ogata, H.Y., 1998. Lysine requirement of juvenile Japanese flounder (Paralichthys olivaceus) and juvenile red sea bream (Pagrus major). Aquaculture 161, 131-142.

Fuller, M.F., McWilliam, R., Wang, T.C., Giles, L.R., 1989. The optimum dietary amino acid pattern for growing pigs: 2 . Requirements for maintenance and for tissue protein accretion. Br. J. Nutr. 62, 255-267.

Furuya, W.M., Botaro, D., Neves, P.R., Silva, L.C.R., Hayashi, C., 2004. Exigência de lisina pela tilápia do nilo na fase de terminação. Ciênc. Rural 34, 1571-1577.

Furuya, W.M., Santos, V.G., Silva, L.C.R., Furuya, V.R.B., Sakaguti, E.S., 2006. Exigências de lisina digestível para juvenis de tilápia-do-nilo. R. Bras. Zootec. 35, 937-942.

Gaylord, T.G., Barrows, F.T., 2009. Multiple amino acid supplementations to reduce dietary protein in plant-based rainbow trout, Oncorhynchus mykiss, feeds. Aquaculture 287, $180-184$.

Glencross, B.D., Booth, M., Allan, G.L., 2007. A feed is only as good as its ingredients-a review of ingredient evaluation strategies for aquaculture feeds. Aquac. Nutr. 13, 17-34.

Grisdale-Helland, B., Hatlen, B., Mundheim, H., Helland, S.J., 2011. Dietary lysine requirement and efficiency of lysine utilization for growth of Atlantic cod. Aquaculture 315, 260-268.

Hagen, S.R., Frost, B., Augustin, J., 1989. Precolumn phenylisothiocyanate derivatization and liquid chromatography of amino-acids in food. J. Assoc. Off. Anal. Chem. 72, 912-916

Kaushik, S.J., 1998. Whole body amino acid composition of European seabass (Dicentrarchus labrax), gilthead seabream (Sparus aurata) and turbot (Psetta maxima) with an estimation of their IAA requirement profiles. Aquat. Living Resour. 11, 355-358.

Kim, J.D., Lall, S.P., 2000. Amino acid composition of whole body tissue of Atlantic halibut (Hippoglossus hippoglossus), yellow-tail flounder (Pleuronectes ferruginea) and Japanese flounder (Paralichthyus olivaceus). Aquaculture 187, 367-373.

Li, P., Mai, K., Trunshenski, J., Wu, G., 2009. New developments in fish amino acid nutrition: towards functional and environmentally oriented aquafeeds. Amino Acids 37, $43-53$.

Mansano, C.F.M., 2015. Digestibilidade e exigência de aminoácidos para rã-touro (Digestibility and Amino Acids Requirement for Bullfrog). (PhD thesis) Universidade Estadual Paulista, Centro de Aquicultura, São Paulo, Brazil (112 pp.)

Mansano, C.F.M., Stéfani, M.V., Pereira, M.M., Macente, B.I., 2013. Avaliação de diferentes locais de implante de microchip para identificação eletrônica de reprodutores de rã-touro e sua validação por meio da análise de imagem. Rev. Bras. Reprod. Anim. 37, 295-297.

Martínez, I.P., Real, M., Álvarez, R., 2004. Growth of Rana perezi Seoane, 1885 froglets fed on diets with different nutrient compositions. Aquaculture 241, 387-394.

Olvera-Novoa, M.A., Ontiveros-Escutia, V.M., Flores-Nava, A., 2007. Optimum protein level for growth in juvenile bullfrog (Rana catesbeiana Shaw, 1802). Aquaculture 266, 191-199.

Sakomura, N.K., Rostagno, H.S., 2007. Método dose-resposta para determinar exigências nutricionais. Métodos de Pesquisa em Nutrição de Monogástricos, Jaboticabal. SP, FUNEP, pp. 156-194.

SAS Institute, 2008. SAS/STAT 9.2. User's Guide. SAS Institute Inc., Cary, NC.

Schneider, U.A., Havlík, P., Schmid, E., Valin, H., Mosnier, A., Oberteiner, M., Bottcher, H., Skalský, R., Balkovic, J., Sauer, T., Fritz, S., 2011. Impacts of population growth, economic development, and technical change on global food production and consumption. Agric. Syst. 104, 204-215

Small, B.C. Soares, J.H., 1998. Estimating the quantitative essential amino acid requirements of striped bass Morone saxatilis, using fillet A/E ratios. Aquac. Nutr. 4, 225-232.

Tibaldi, E., Lanari, D., 1991. Optimal dietary lysine levels for growth and protein utilisation of fingerling sea bass (Dicentrarchus labrax L.) fed semipurified diets. Aquaculture 95, 297-304.

Twibell, R.G., Griffin, M.E., Martin, J., Price, J., Brown, P.B., 2003. Predicting dietary essential amino acid requirements for hybrid striped bass. Aquac. Nutr. 9, 373-381.

Wang, T.C., Fuller, M.F., 1989. The optimum dietary amino acid pattern for growing pigs. 1. Experiments by amino acid deletion. Br. J. Nutr. 62, 77-89.

Wang, S., Liu, Y.J., Tian, L.X., Xie, M.Q., Yang, H.J., Wang, Y., Liang, G.Y., 2005. Quantitative dietary lysine requirement of juvenile grass carp Ctenopharyngodon idella. Aquaculture 249, 419-429.

White, J.A., Hart, R.J., Fry, J.C., 1986. An evaluation of the waters pico-tag system for the amino-acid-analysis of food materials. J. Autom. Chem. 8, 170-177.

Yamamoto, T., Shima, T., Furuita, H., Suzuki, N., Sânchez-Vâzquez, F.J., Tabata, M., 2000. Self-selection of diets with different amino acid profiles by rainbow trout (Oncorhynchus mykiss). Aquaculture 187, 375-386.

Yamamoto, T., Shima, T., Furuita, H., Suzuki, N., Sanchez-Vazquez, F.J., Tabata, M., 2001. Self-selection and feed consumption of diets with a complete amino acid composition and a composition deficient in either methionine or lysine by rainbow trout, Oncorhynchus mykiss (Walbaum). Aquac. Res. 32, 83-91. 